\title{
MODERN MUSICAL EDUCATION OF FEDERAL REPUBLIC OF GERMANY
}

\author{
Ovcharenko Natalia, Doctor of Pedagogical Sciences, Associate Professor, Kryvyi Rih State Pedagogical \\ University, 54 Gagarina Str., 50086 Kryvyi Rih, Ukraine, shvager77@gmail.com
}

This article is based on actuality and importance of learning foreign experience in sphere of musical education. For constant systems of art education of Europe, that devote individual view, such as developed musical education in Federal Republic of Germany. That's why for main tasks of exploration refer basement of international direction of modern European musical education, definition of peculiarities and directions of development in musical education of Germany. For determination of peculiarities in professional training of future professional musician in Germany was looked through organization of educational process in Munchen's high school of music and theatre and Leipzig's university of music and theatre by Felix Mendelssohn Berthold. Analytic viewing of modern education in Germany, gives an opportunity to determine its peculiarities, such as musical and musical pedagogical education, that represent constant system and have historically checking out traditions with the time, new social conditions, that connects with the development of globalization, spreading of dialogues in culture of folks in the world, using innovational technologies are counted in modern musical education of country, there are necessity in reinforcing of connections between schools of musical education during the life, professional training of future professionals musicians (performers and teachers) that represent in state and state accreditation educational institution of Germany such as universities, conservatories and high schools of music in country, system of musical education in country, that includes the training of musical professionals for two innovational (bachelor for 3-4 years and master for 1-2 years) or traditional educational (diplomas of specialist for specialties) levels, German's postgraduate course is a third level in Bologna process in 2-4 years or second, due to traditional system of education that finished with writing and of dissertation defending and devoting of science level-candidate of science, content of training of future professionals in musical art necessary includes innovational component, that helps satisfaction in professional needs of modern student of Germany.

Keywords: foreign experience; integration process; musical education of Germany; professionals of musical art.

Стаття надійшла до редакції 10.04.2017

Прийнято до друку 25.05.2017

УДК 373.5-044.227:5](100+477)

Наталія Лакоза

ORCID iD 0000-0002-8741-5967

кандидат педагогічних наук, науковий співробітник відділу створення навчально-тематичних систем знань,

НЦ «МАН України»,

вул. Мельникова, 63, 04050 м. Київ, Україна,

26-04@i.ua

\section{ОРГАНІЗАЦІЯ ПРОФІЛЬНОГО НАВЧАННЯ В УКРАЇНІ ТА ЗА КОРДОНОМ}

У статті розглядається становлення профільного навчання природничого напрямку в системі довузівської підготовки України. Проаналізовано різні підходи щодо складання навчальних планів профільних дисциплін; особливості організацї профільного навчання учнів у школах України та країн зарубіжжя. Для профільного навчання останніх характерним є інтегрований підхід до викладання дисциплін, а також залучення учнів до науково-дослідницької діяльності на базі університетів.

Аналіз функціонування старшої школи країн Свропи, Америки та Японії дає змогу акцентувати увагу на позитивних національних особливостях та виокремити загальні принщипи розвитку довузівської підготовки обдарованої молоді.

Ключові слова: довузівська підготовка; медико-біологічна освіта; обдарована молодь; профільне навчання.

Вступ. Процеси інтеграції, глобалізації та інформатизації суспільства визначили нові пріоритети розвитку освітньої галузі в Україні.
Вихідні положення модернізації освіти щодо підготовки учнів загальноосвітніх навчальних закладів до майбутньої професійної діяльності 
природничого напряму висвітлено у Концепції профільного навчання (2003). Відповідно до Концепції профільна освіта має бути більш індивідуалізованою, функціональною та ефективною, зорієнтованою на потреби і запити як особистості учня, так і суспільства. Сучасний фахівець повинен оволодіти відповідним обсягом знань і вмінь з природничих дисциплін, критично осмислювати та використовувати наукову інформацію, а також діяти методами, категоріями науки у своїй професійній діяльності. Сучасна біологічна освіта спирається на використання новітніх технологій навчання, що зумовлено зростанням ролі інформації в суспільстві й компетенцій до раціональної, продуктивної творчої діяльності. Як показав аналіз навчальних програм, диференціація здійснюється, здебільшого, шляхом ускладнення наукового змісту, а способи його засвоєння, як правило, не враховуються. Це вимагає залучення нових методичних підходів в організації профільного навчання школярів. У зв’язку 3 цим актуальним є вивчення досвіду організації профільного навчання в Україні та у розвинених країнах світу.

Проблемі профільного навчання у загальноосвітніх навчальних закладах приділяється належна увага у психолого-педагогічних дослідженнях багатьох авторів, зокрема, таким її аспектам: формуванню мотивів інтелектуально-творчої діяльності в роботах В. І. Андрєєва, С. О. Сисоєвої, В. С. Шубинського; формування творчої особистості учня у профільних ліцеях розглядається в роботах В. Ф. Паламарчук, Я. В. Цехмістера; дослідження С. С. Барбіної, В. І. Бондаря та Г. С. Сазоненко присвячені ефективності профільного навчання за умови забезпечення його цілісності. Аналіз зарубіжного досвіду впровадження профільного навчання в старшій школі здійснено в роботах А. І. Галагана, Г .С. Єгорова, М. Ю. Красовицького, О. І. Локшиної.

Метою статті є висвітлення особливостей організації профільного навчання в Україні та за кордоном, спрямованих на розвиток особистості.

Різноманітні підходи профілізації старшої школи. Країни Свропейського Союзу приділяють значну увагу питанню освіти обдарованих дітей. Парламентська асамблея СС прийняла у 1994 році рекомендації щодо розвитку обдарованих дітей (Рекомендації (1248) щодо розвитку освіти обдарованих і талановитих дітей, 1994). У більшості країн ЄС існує система спеціалізованих шкіл для обдарованих дітей, започаткована у 2005 році (Monks F., Pfluger R., 2005).

Розвиток світового i, зокрема, європейського простору, об'єктивно вимагає від української школи адекватної реакції на процеси реформування загальної середньої школи, що відбувається у провідних країнах світу. Загальною тенденцією розвитку старшої профільної школи є їі орієнтація на широку диференціацію, варіативність, багато- профільність, інтеграцію загальної і допрофесійної освіти (Концепція профільного навчання у старшій школі, 2003).

Сучасні середні загальноосвітні заклади Німеччини розподіляються на середні школи нижчого та вищого рівнів. Започаткування профільного навчання відбувається на нижчому рівні середньої школи,яке розширюється потім на вищому рівні середньої освіти. Поглиблена спеціалізація розпочинається після успішного завершення 10 класу гімназії, з 11класу. Тривалість навчання у гімназії складає 3 роки. Навчання у гімназї базується на принципах дитино-зорієнтованості і побудовано з урахуванням індивідуальних потреб учнів. Вищий рівень навчання підсумовується випускним іспитом. Навчальні плани з основ наук створюються, в основному, за лінійним принципом, відповідно дидактичному принципу систематичності й послідовності, що виключає дублювання матеріалу. Поряд з цим, останнім часом впроваджується принцип концентричності розташування матеріалу, який базується на повторі його в окремих розділах програми на кількох ступенях навчання й більш глибокому проникненні у сутність явищ і процесів, що вивчаються (Старша школа зарубіжжя: організація та зміст, 2006).

Біологія не займає у школах домінуючого положення серед навчальних предметів. Про це свідчить Таблиця 1, в якій наведені дані про кількість годин біології на тиждень, у школах різних країн Свропи (Лакоза Н. В., 2000) (тут введені умовні позначення: «-» означає, що в цьому віці нема навчання біології; «0» - біологічні питання не вивчаються; «1 (2 та інші)» - кількість годин біології, які включені в інші курси; «1б (2б та інші)» - кількість годин окремого курсу біології).

Таблиця 1 вказує на той факт, що більшість країн Європи має 12-річну шкільну освіту. Зокрема, в Австрії, години біології включені в інші курси і вивчаються інтенсивно в початковій школі. Окремі біологічні дисципліни та загальна біологія вивчаються протягом 6 років в школах та гімназіях, включаючи 12 клас. Подібна структура планування годин біології спостерігається і у Франції, але кількість годин біології в структурі інших дисциплін початкової школи зменшено вдвічі. Закінчується вивчення біології в 10-ому класі школи.

Спеціальні біологічні дисципліни (ботаніка, зоологія) викладаються з 1-ого класу шкіл тільки в Англії та Італії, але вивчення біології в цих країнах закінчується в 8-9 класах більшості шкіл. У школах Данії, Фінляндії, Норвегії, Швеції та Швейцарії самостійний курс біології учні вивчають у віці 12-13 років. Після закінчення основної школи та вступного іспиту близько 40\% молоді вступають у гімназії з трирічним курсом навчання, в яких біологія вивчається лише 1 рік.

У старших класах гімназій біологія вивчається за вибором учнів - на середньому або на висо- 
кому рівнях, 4-5 годин на тиждень. Довузівська підготовка включає навчання за 10 профілями і складає 31 годину на тиждень. Наприклад, у Франції учні, які здобувають середню освіту, вивчають біологію лише в ліцеях. Принципом навчання $€$ меритократизм, який полягає в припущенні, що успіхи в освіті й подальшому розвитку соціального статусу особи є результатом поєднання її здібностей та індивідуальних зусиль. На вищому ступені гімназії, у 2-ому класі, навчання зорієнтовано на дисципліни, які необхідні для вступу в університет. У курсі біології основна увага приділяється вивченню екології, фізіології, біохімії, генетики та еволюції. Оцінювання знань учнів проводяться на всіх трьох ступенях гімназій - по три оцінки на рік, з обов'язковим іспитом у кінці курсу. Учні гімназії повинні також підготувати по 5-10 доповідей, які є складовою частиною практикуму.

Таким чином, в країнах Європи можна помітити розмежування в орієнтації на дисципліну і на про- блему. Варто зазначити, що донедавна в країнах Заходу існував жорсткий розподіл між академічним та професійно-технічним напрямами, тому перехід учнів з одного напряму до іншого був практично неможливим. Новітньою тенденцією розвитку старшої школи у цьому контексті є інтеграція академічного та професійно-технічного напрямів освіти. Це означає усунення жорсткого розподілу між напрямами, можливість отримання вищої освіти технічного характеру для молоді, що обрала академічний напрям і навпаки.

Науково-педагогічні засади американської освіти мають плюралістичний характер і зосереджені на проблемах організації, структури навчання шкіл для обдарованих дітей; змісту шкільної освіти для запобігання шкідливих звичок. Новітньою тенденцією є спроба інтеграції дітей з особливими потребами до звичайних дитячих колективів.

Шкільна біологічна освіта в країнах Європи

Таблиця 1

\begin{tabular}{|c|c|c|c|c|c|c|c|c|c|c|c|c|c|c|c|}
\hline \multirow{3}{*}{ Країна } & \multicolumn{15}{|c|}{ Кількість годин у тиждень, відведені для вивчення біології у різних за віком групах учнів } \\
\hline & \multicolumn{13}{|c|}{ Вік учнів, що навчаються } & \multicolumn{2}{|c|}{$\begin{array}{c}\text { Загальна кількість } \\
\text { годин }\end{array}$} \\
\hline & 6 & 7 & 8 & 9 & 10 & 11 & 12 & 13 & 14 & 15 & 16 & 17 & 18 & $\begin{array}{l}\text { в усіх } \\
\text { курсах }\end{array}$ & $\begin{array}{l}\text { в курсах } \\
\text { біоло-гії } \\
\end{array}$ \\
\hline Австрія & 4 & 4 & 4 & 4 & Зб & 26 & 0 & 26 & 26 & Зб & 0 & $2 \sigma$ & - & 30 & 14 \\
\hline Бельгія & 1 & 1 & 1 & 1 & 16 & 16 & 2 & 26 & 16 & 16 & 0 & 0 & - & 12 & 6 \\
\hline Данія & - & 0 & 0 & 1 & 1 & 1 & 26 & 26 & 0 & 0 & Зб & 0 & 0 & 10 & 7 \\
\hline Англія & 0,56 & 0,56 & 0,56 & 0,56 & 0,56 & 16 & 16 & 16 & 0 & 0 & 0 & 0 & 0 & 5,5 & 5,5 \\
\hline Фінляндія & - & 0 & 0 & 1,56 & 1,56 & 1,56 & 1,56 & 16 & 16 & 1,5 & 0 & 26 & 16 & 12,5 & 11 \\
\hline Франція & 2 & 2 & 2 & 2 & 26 & 26 & 26 & 26 & 26 & 16 & 0 & 0 & - & 19 & 11 \\
\hline Турція & 0 & 1 & 1 & 1 & 26 & 26 & 16 & 0 & 16 & 16 & 0 & 0 & 0 & 10 & 7 \\
\hline Ісландія & - & 1 & 1 & 1 & 1,56 & 1,56 & 26 & 26 & 26 & 0 & 0 & 0 & 0 & 12 & 9 \\
\hline Ірландія & 1 & 1 & 1 & 1 & 1 & 1 & 0 & 0 & 0 & 0 & 0 & 0 & - & 6 & 0 \\
\hline Італія & 16 & 16 & 26 & 26 & 26 & 2 & 2 & 2 & 0 & 0 & 26 & 0 & 0 & 16 & 10 \\
\hline Нідерланди & 0,5 & 0,5 & 1 & 1 & 4 & 4 & 26 & 26 & 0 & 0 & 0 & 0 & 0 & 15 & 4 \\
\hline Норвегія & - & 0 & 0 & 0 & 2 & 2 & 3 & 3 & 2 & 3 & 2 & 0 & 0 & 17 & 0 \\
\hline Португалія & 1 & 1 & 1 & 1 & 1 & 1 & 1,5 & 26 & 26 & 56 & 36 & - & - & 19,5 & 12 \\
\hline Іспанія & 1,5 & 1,5 & 1,5 & 1,5 & 1,5 & 2 & 0 & 1 & Зб & 0 & 0 & 0 & - & 13,5 & 3 \\
\hline Швейцарія & - & 0 & 0 & 0 & $2 б$ & 26 & $2 б$ & Зб & 0 & Зб & 26 & 0 & 0 & 14 & 14 \\
\hline Швеція & 0 & 0 & 0 & 0 & 2 & 2 & 26 & 1,56 & 1,56 & 1,56 & 0 & 0 & - & 10,5 & 6,5 \\
\hline Україна & - & 2 & 2 & 2 & 1 & 26 & 26 & 26 & 26 & 16 & $1-26$ & - & - & 17,5 & 10,5 \\
\hline Росія & - & 1 & 1 & 1 & 1 & 26 & 26 & 26 & $2 б$ & 16 & 26 & - & - & 15 & 11 \\
\hline
\end{tabular}

Середні державні школи США, де навчаються 85\% дітей, мають дуже добру матеріально-технічну базу, що дозволяе здійснювати якісну допрофільну підготовку учнів. Елітні старші школи, які мають різні напрямки профілізації, проводять кон- курсний відбір учнів за допомогою іспитів. Старші школи підтримують широкі зв'язки з коледжами та університетами, проводять наукові конференції та конкурси для виявлення талановитої молоді. (Старша школа зарубіжжя: організація та зміст 
освіти, 2006, с. 232). Домінуючим фактором функціонування освіти США, на нашу думку, є принцип демократичності, який пов'язаний з індивідуальним вибором навчальних курсів, гнучкому розкладі навчальних дисциплін і довільному встановленні тривалості уроку - від 35 до 90 хвилин. У вивченні предметів природничого циклу значна увага приділяється практичній спрямованості навчання, постановці експериментальних робіт. Цьому сприяє оснащеність навчальних лабораторій, доступ до використання ресурсів глобальної мережі Internet. На уроках біології вивчення живих організмів пов'язано з використанням сучасних мікроскопів, препаруванням організмів, використанням сучасних комп'ютерних технологій у навчанні. Реалізація принципу «від практики до теорії» дозволяє учням, залежно від своїх потреб та допитливості, засвоїти навчальний матеріал від натурного споглядання до теоретичних основ (Галаган А. И., 1988, с. 52). Більшість американських спеціальних шкіл є відповідними факультетами університетів i, лише, окремі медичні школи являють собою самостійні навчальні заклади. Особливістю навчання у медико-біологічних школах є комплексний, інтегрований підхід до вивчення спеціальних дисциплін, проблемне навчання й самостійне добування знань, де особлива увага приділяється практичним заняттям на базі клінік. Для перевірки рівня знань використовується тестування.

Система підготовки в Японії спрямована на розв'язання двох взаємозв'язаних проблем: управління змістом навчання, управління організацією навчального процесу. Підготовка фахівців медико-біологічного напряму Японії орієнтована на кінцеві результати професійної діяльності: методика навчання об'єднує теоретичні знання та дії, проводиться робота по корекції змісту навчання з урахуванням кваліфікаційних вимог (Галаган А. И., 1989, с. 60).

В Україні встановлено інваріантний (базовий) та варіативний компоненти освіти, які визначаються центральними органами державного управління освіти на підставі співвідношення відповідно $(70 \div 80) \%$ (базовий) та $(30 \div 20) \%$ (варіативний).

Практичного втілення профільне навчання в Україні набуло у 20-х роках XX століття відповідно трудового навчання і професійній підготовці школярів. Починаючи з 1932 року в Західній Україні було введено нову систему освіти, яка базувалася на Концепції єдиної школи: початкова - середня вища. Позитивним у цій системі було впровадження неперервної освіти, взаємозв'язок програм.

Протягом $50-\mathrm{x}$ років почали створюватись спеціалізовані школи різних напрямів для обдарованих дітей, а трудова підготовка була перетворена на професійно-технічну. Існували й училища, в яких отримували медико-біологічну освіту прикладного характеру - медичної сестри, фармацевта, фельдшера.
Педагогічна наука вела пошук шляхів розвитку творчих можливостей учнів, вбачаючи їх у диференційованому навчанні в рамках діючих стандартів. На думку С. У. Гончаренка, цим самим школа все робила для того, щоб згасити природні для віку вогники допитливості, інтересу, потяг до творчості, щоб згодом випустити іх у життя усередненими і часто 3 відразою до навчання (Гончаренко С. У.,1994, с. 2-3).

Принцип єдиної школи передбачав єдність мети і завдань загальної політехнічної освіти, забезпечення випускникам усіх типів середніх шкіл повноцінних знань $з$ основ наук (Бондар В. І., 2000, с. 191).

Упродовж 60-х років почали відкриватись спеціалізовані загальноосвітні школи та класи 3 поглибленим вивченням окремих предметів та факультативів. Ліцейні класи природничого, медико-біологічного напряму, в умовах кризових явищ в країні на початку і впродовж 90-х років, були осередками накопичення інтелектуального потенціалу молоді. Це означало відмову від роботи школи на «середнього учня» і до приділення уваги інтелектуальній діяльності найсильнішого учня.

Профільне навчання надає можливість обрати школярам конкретну галузь для глибокого вивчення, оскільки сукупність предметів цієї галузі на інтегративній основі, на спільному понятійному апараті та засобах навчання доповнюють один одного. Вивчення кількох предметів часто запобігає вузькій спеціалізації навчання.

Відповідно Концепції, через профільне навчання у загальноосвітніх навчальних закладах у 2001-2002 навчальному році було охоплено 401286 учнів (6,3\%), а у 2002-2003 навчальному році - 430569 учнів (6,9\%). Найвищі показники у виборі профільного навчання спостерігаються на користь суспільно-гуманітарного, інформатики та обчислювальної техніки, філологічного напрямів. Поряд 3 цим, кількість навчальних закладів природничого, екологічного, профілів навчання значно мала. Майже така тенденція збереглась і до теперішнього часу.

Метою профільного навчання на сучасному етапі є забезпечення можливостей для рівного доступу учнівської молоді до здобуття загальноосвітньої, профільної та початкової допрофесійної підготовки, неперервної освіти впродовж усього життя. Профільне навчання спрямоване на здобуття старшокласниками навичок самостійної науково-практичної, дослідницько-пошукової діяльності, розвиток іхніх інтелектуальних, творчих, соціальних якостей, прагнення до саморозвитку та самоосвіти. Форми організації профільного навчання регламентують діяльність навчальних закладів і забезпечують умови для реалізації навчально-виховного процесу певного напряму. Профільні класи відкриваються на базі загальноосвітніх навчальних закладів за умови їх наповнення, але цьому сприяє допрофільна підготовка (Лакоза Н. В.,1994, c. 105-107). 
Проблема щодо створення неперервної медико-біологічної освіти була поставлена у 1989 році ректором НМУ Є. Г. Гончаруком (Цехмістер Я. В., 2002). У 1990 році на базі НМУ імені О. О. Богомольця і загальноосвітньої школи 93 почав працювати перший експериментальний клас медико-біологічного профілю м. Києва, в який було прийнято учнів, зацікавлених біологією. В процесі організації навчання для учнів медико-біологічного класу нами було складено навчальні плани, програми лабораторних та факультативних занять. Створення позитивного мікроклімату, блоково-модульна організація навчання сприяли розвитку творчих можливостей учнів (Сисоєва С. О., Лакоза Н. В., 1991, c. 74-76).

У контексті нашого дослідження учні медикобіологічного класу загальноосвітньої школи №93 м. Києва мали можливість поглиблено вивчати хімію, фізику, біологію, відповідні факультативи та спецкурси на кафедрах НМУ. Майже 75\% випускників профільного навчання стали студентами вищих учбових закладів медико-біологічного і природничого напрямів.

При організації навчально-виховного процесу в профільних класах ми виходили з того, що на методологічному рівні підготовка школярів до медико-біологічної освіти повинна використовувати не предметно-дисциплінарний підхід, а інтегративний, для якого характерним $е$ взаємопроникнення основного змісту середньої освіти і варіативної його частини. Так, наприклад, курс біології людини закінчується в 9-му класі, а в 11-му за чинною програмою продовжує формуватись в учнів наукове поняття «обмін речовин». 3 метою неперервності формування цього поняття ми вводимо в 10-му профільному класі спецкурс «Фізіологія людини», який має розширити обсяг багатьох фізіологічних понять, пов'язаних з науковим поняттям «обмін речовин». Отже, важливою тенденцією профілізації навчання у профільних і ліцейних класах є відбір і структурування навчального матеріалу навколо фундаментальних ідей, теорій, суттєвим елементом яких є наукові поняття.

Принцип науковості є головним орієнтиром у відборі основних наукових понять відповідно сучасному рівню розвитку біології, природничих наук. Принцип наступності забезпечується наявністю неперервних зв'язків етапів формування наукових понять з біології у допрофільному та профільному навчанні. Інтегративний підхід передбачає використання у навчально-виховному процесі інтегрованих уроків та інтегрованих завдань, що сприяють підвищенню мотивації до навчання, встановленню зв'язків між поняттями.

В Україні впродовж останніх 10 років успішно працюють понад 20 ліцеїв та гімназій, які мають медико-біологічний, природничий профілі навчання. Розширюється мережа профільних класів при університетах.
Діяльність ліцеїв дозволяє в майбутньому здійснити цільову підготовку спеціалістів відповідного профілю, зміцнити науковий потенціал навчального закладу, залучаючи вчених вузів, використовуючи передові педагогічні та інформаційні технології, дистанційне навчання (Грицай Н. Б., 2016).

Навчальні плани сучасних ліцеїв України відрізняються, оскільки структура цих планів відповідає різній практичній меті ліцеїв. Разом 3 тим, в навчальних планах можна виділити три основні блоки: блок загальноосвітньої підготовки, блок профільного навчання, блок професійної практичної підготовки.

Згодом, при Національному медичному університеті були створені медико-біологічні класи, потім два державні ліцеї, а у 1997 році Український медичний ліцей, які були і залишаються важливим компонентом в системі неперервної медико-біологічної освіти.

Отже, діяльнісна складова на уроках біології в нашому дослідженні реалізується у самостійному використанні учнями правил наукової організації розумової праці, а саме: проведення аналізу й синтезу, узагальнення; складання конспекту, тез, рефератів. Згідно експериментальної методики процес формування наукових понять з біології в учнів класів медико-біологічного профілю пов'язаний з розвитком у них таких особистісних якостей, розумових, практичних умінь, що сприятимуть пошуково-творчій діяльності, результатом якої $е$ подальший саморозвиток майбутнього фахівця як дослідника.

Специфіка лікарської діяльності, об’єктом якої є людина, визначає необхідність постійного її вдосконалення, особистісно-орієнтовний підхід у навчанні, формування наукових понять, які є базовими для подальшого навчання. Це вимагає створення системи неперервної медико-біологічної освіти, що включає профорієнтацію, навчання у навчальному закладі, післядипломну підготовку.

Висновки. Більшість європейських країн мають 12-річну шкільну освіту, обдарована молодь навчається в гімназіях за 10 профілями, де біологію вивчають за вибором. Медико-біологічна підготовка здійснюється у коледжах, школах при університетах, для яких характерним $€$ інтегрований підхід до вивчення біологічних дисциплін, науководослідницька діяльність, проблемне навчання й самостійне оволодіння знаннями. Перевіркою рівня знань є тестування.

Перспективи подальших наукових пошуків ми вбачаємо у розробці й апробації програм для базових та профільних предметів, спецкурсів, факультативів, застосування сучасних засобів навчання. 


\section{Література}

1. Бондар В. І. Теорія і технологія управління процессом навчання в школі: Навчальний посібник / В. І. Бондар. - К.: вид-во АПН України, 2000. - 191 с.

2. Галаган А. И. Система образования в США / А. И. Галаган, Г. И. Полянская // Проблема зарубежной высшей школы: Обзор информации. НИИВШ.- М., 1988. - Выпуск 4. - 52 с.

3. Галаган А. И. Система образования в Японии / А. И. Галаган // Проблема зарубежной высшей школы: Обзор информации. - М., 1989. - 60 с.

4. Гончаренко С. У. Проблеми інтеграції змісту шкільної освіти / С. У. Гончаренко // Інтеграція елементів змісту освіти: Матеріали Всеукраїнської науково-практичної конференції. - Полтава, 1994. - С. 2-3.

5. Грицай Н. Б. Використання дистанційних технологій у методичній підготовці майбутніх учителів біології [Електронний ресурс] / Н. Б. Грицай // 2016, DOI: 10.14308/ite000586. - Режим доступу: http://ite. kspu.edu/webfm_send/883

6. Концепція профільного навчання у старшій школі / Ін-т педагогіки АПН України; уклад. Л. Березівська, Н. Бібік, М. Бурда та ін. // Освіта України. - 2003. - № 88. - С. 4-5.

7. Лакоза Н. В. Особливості організації навчального процесу в спеціалізованих класах медикобіологічного профілю / Н. В. Лакоза // Актуальні проблеми розвитку творчих можливостей учнів:Тези доповідей Всеукраїнської наукової конференції. -К.: ІСДО, 1994. - С. 105-107.

8. Лакоза Н. В. Формування наукових понять з природничих дисциплін - проблема неперервної освіти. Теорія і практика формування професійної компетентності суб’єктів педагогічного процесу / Н. В. Лакоза // Проблеми сучасного мистецтва і культури. - Х. Каравела, 2000. - С. 82-92.

9. Рекомендації (1248) щодо розвитку освіти обдарованих і талановитих дітей [Електронний ресурс]. Режим доступу: http: www.eurotalent.org/11-1a-recommandation-1248-relative-a-leducation-des-enfanssurdoues/

10. Сисоева С. А. А бабочек ловили... раки / С. А. Сисоева, Н. В. Лакоза // Народное образование, 1991. - № 10. - C. 74-76.

11. Старша школа зарубіжжя: організація та зміст освіти / За ред. О. І. Локшиної. - К.: СПД Богданова A. M., 2006. - 232 c.

12. Цехмістер Я. В. Теорія і практика допрофесійної підготовки учнів у ліцеях медичного профілю при вищих навчальних закладах: Дис. доктора пед. наук: 13.00.04 / Я. В. Цехмістер. - К., 2002. - 640 с.

13. Monks F. Gifted education in 21 European Countries: Inventory and perspective / F. Monks, R. Pfluger. Nijmegen: Radboud University, 2005. - 172 p.

\section{References}

1. Bondar V. I. (2000). Teoriia i tekhnolohiia upravlinnia protsessom navchannia v shkoli [The theory and technology of controlling the process of studying in a school]. K.: APN Ukrainy, 191 (ukr).

2. Galagan A. I. (1988). Sistema obrazovanija v SShA [Educational system in the USA]. Problema zarubezhnoj vysshej shkoly: Obzor informacii. NIIVSh. M., 4, 52 (rus).

3. Galagan A. I. (1989). Sistema obrazovanija v Japonii [Education system in Japan]. Problema zarubezhnoj vysshej shkoly: Obzor informacii. M., 60 (rus).

4. Honcharenko S. U. (1994). Problemy intehratsii zmistu shkilnoi osvity [Problems of integration of the contents of school education]. Intehratsiia elementiv zmistu osvity: Proceedings of the All-Ukrainian Scientific and practical Conference. Poltava, 2-3 (ukr).

5. Hrytsai N. B. (2016). Vykorystannia dystantsiinykh tekhnolohii u metodychnii pidhotovtsi maibutnikh uchyteliv biolohii [The use of remote technology in the methodological training of future biology teachers]. DOI: 10.14308/ite000586. Available at: http://ite.kspu.edu/webfm_send/883 (ukr).

6. Berezivska L., Bibik N., Burda M. (2003). Kontseptsiia profilnoho navchannia u starshii shkoli [Concept of profile education in high school]. Osvita Ukrainy. K.: In-t pedahohiky APN Ukrainy, 88, 4-5 (ukr).

7. Lakoza N. V. (1994). Osoblyvosti orhanizatsii navchalnoho protsesu v spetsializovanykh klasakh medykobiolohichnoho profiliu [Features of organization of educational process in specialized classes of medical-biological profile]. Aktualni problemy rozvytku tvorchykh mozhlyvostei uchniv: Abstracts of Papers of the All-Ukrainian Scientific Conference. K.: ISDO, 105-107 (ukr).

8. Lakoza N. V. (2000). Formuvannia naukovykh poniat z pryrodnychykh dystsyplin - problema neperervnoi osvity. Teoriia i praktyka formuvannia profesiinoi kompetentnosti subiektiv pedahohichnoho protsesu [Formation of scientific concepts in natural sciences - the problem of continuous education. Theory and practice of forming the professional competence of subjects of the pedagogical process]. Problemy suchasnoho mystetstva i kultury. Kh.: Karavela, 82-92 (ukr).

9. Rekomendatsii (1248) shchodo rozvytku osvity obdarovanykh i talanovytykh ditei [Recommendations (1248) for the development of gifted and talented children]. Available at: http: www.eurotalent.org/11-1arecommandation-1248-relative-a-leducation-des-enfans-surdoues/, (fre). 
10. Sisoeva S. A., Lakoza N. V. (1991). A babochek lovili... raki [And the butterflies were caught ... crayfish]. Narodnoe obrazovanie., 10, 74-76 (rus).

11. Lokshyna O. I. (2006). Starsha shkola zarubizhzhia: orhanizatsiia ta zmist osvity [Senior School of Abroad: Organization and Content of Education]. O. I. Lokshyna (Ed.). K.: SPD Bohdanova A. M., 232 (ukr).

12. Tsekhmister Ya. V. (2002). Teoriia i praktyka doprofesiinoi pidhotovky uchniv u litseiakh medychnoho profiliu pry vyshchykh navchalnykh zakladakh [Theory and practice of pre-professional preparation of students in medical school lyceums at higher educational institutions]: Doctor's thesis. K., 640 (ukr).

13. Monks F., Pfluger R. (2005). Gifted education in 21 European Countries: Inventory and perspective. Nijmegen: Radboud University, 172 (eng).

\section{ОРГАНИЗАЦИЯ ПРОФИЛЬНОГО ОБУЧЕНИЯ В УКРАИНЕ И ЗА РУБЕЖОМ}

Лакоза Наталия, кандидат педагогических наук, научный сотрудник отдела создания учебно-тематических систем знаний, НЦ «МАН Украины», ул. Мельникова, 63, 04050 г. Киев, Украина, 26-04@i.ua

В статье рассматривается становление профильного обучения естественнонаучного направления в системе довузовской подготовки Украины. Проанализированы различные подходы к составлению учебных планов профильных дисциплин; особенности организации профильного обучения учеников в школах Украинъь и стран зарубежья. Для профильного обучения последних характерным является интегрированный поход $к$ преподаванию дисииплин, а также вовлечение учеников в научно-исследовательскую деятельность на базе университетов.

Анализ функиионирования старшей школы стран Европь, Америки и Японии даёт возможность акцентировать внимание на положительных национальных особенностях и выделить общие принципы развития довузовской подготовки талантливой молодежи.

Ключевые слова: довузовская подготовка; медико-биологическое образование; профильное обучение; талантливая молодежь.

\section{PROFILE EDUCATION ORGANIZATION IN UKRAINE AND ABROAD}

Lakoza Natalia, $\mathrm{PhD}$, researcher in the Unit for Creating Educational and Thematic Knowledge Systems, research center in Minor Academy of Sciences of Ukraine, 63 Melnikova Str., 04050 Kyiv, Ukraine, 26-04@i.ua

In the article it was considered the formation of profile studying in the sphere of natural sciences in the system of pre-university studying. Different approaches for making curricula of profile subjects, features of senior's profile training organization in Ukrainian and foreign lyceums, gymnasiums were analyzed. The experience of the leading lyceum organization of Ukraine was considered.

It was found that the majority of European countries have twelve-year schooling. The idea of using interdisciplinary connections, science and technology cooperation is a feature of studying programs based on sciences. It can be achieved by living and learning combination, improving practical works and using modern computer technologies in the studying process. Most of the profile studies are conducted in different lyceums and gymnasiums, which have the integral approach to the study of sphere of nature. What's more, these education establishments encourage students to take part in scientific researches, based on university system of education.

Analysis of the functioning of European, American and Japanese high schools gives an opportunity to focus on national features, to single out general principles of pre-university trainings.

Keywords: medical and biological education; pre-university training; studying profile; talented youth.

Стаття надійшла до редакції 05.04.2017

Прийнято до друку 25.05.2017 